\title{
Psychological capital and organisational citizenship behaviour in selected public hospitals in the Eastern Cape Province of South Africa
}

\begin{tabular}{|c|c|}
\hline \multicolumn{2}{|c|}{$\begin{array}{l}\text { Authors: } \\
\text { Shingirayi F. Chamisa }{ }^{1} \\
\text { Temba Q. Mjoli } \\
\text { Tatenda S. Mhlanga }\end{array}$} \\
\hline \multicolumn{2}{|c|}{$\begin{array}{l}\text { Affiliations: } \\
\text { }{ }^{1} \text { Department of Industrial } \\
\text { Psychology, Faculty of } \\
\text { Economic and Management } \\
\text { Sciences, University of the } \\
\text { Free State, Phuthaditjhaba, } \\
\text { South Africa }\end{array}$} \\
\hline $\begin{array}{l}{ }^{2} \text { Department } \\
\text { Psychology, Fa } \\
\text { Management } \\
\text { University of } \\
\text { South Africa }\end{array}$ & $\begin{array}{l}\text { f Industrial } \\
\text { culty of } \\
\text { and Commerce, } \\
\text { ort Hare, Alice, }\end{array}$ \\
\hline \multicolumn{2}{|c|}{$\begin{array}{l}\text { Research Project Registration: } \\
\text { Project Number: } 814\end{array}$} \\
\hline \multicolumn{2}{|c|}{$\begin{array}{l}\text { Corresponding author: } \\
\text { Shingirayi Chamisa, } \\
\text { chamisasf@ufs.ac.za }\end{array}$} \\
\hline \multicolumn{2}{|c|}{$\begin{array}{l}\text { Dates: } \\
\text { Received: } 20 \text { June } 2019 \\
\text { Accepted: } 29 \text { Sept. } 2020 \\
\text { Published: } 04 \text { Dec. } 2020\end{array}$} \\
\hline \multicolumn{2}{|c|}{$\begin{array}{l}\text { How to cite this article: } \\
\text { Chamisa, S.F., Mjoli, T.Q., \& } \\
\text { Mhlanga, T.S. (2020). } \\
\text { Psychological capital and } \\
\text { organisational citizenship } \\
\text { behaviour in selected public } \\
\text { hospitals in the Eastern } \\
\text { Cape Province of South Africa. } \\
\text { SA Journal of Human Resource } \\
\text { Management/SATydskrif vir } \\
\text { Menslikehulpbronbestuur, } \\
\text { 18(0), a1247. https://doi.org/ } \\
\text { 10.4102/sajhrm.v18i0.1247 }\end{array}$} \\
\hline \multicolumn{2}{|c|}{$\begin{array}{l}\text { Copyright: } \\
\text { (C) 2020. The Authors } \\
\text { Licensee: AOSIS. This } \\
\text { is licensed under the } \\
\text { Creative Commons } \\
\text { Attribution License. }\end{array}$} \\
\hline \multicolumn{2}{|l|}{ Read online: } \\
\hline 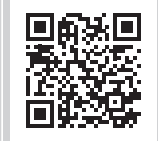 & $\begin{array}{l}\text { Scan this QR } \\
\text { code with your } \\
\text { smart phone or } \\
\text { mobile device } \\
\text { to read online. }\end{array}$ \\
\hline
\end{tabular}

Orientation: The relationship between psychological capital (PsyCap) and organisational citizenship behaviour (OCB) is important to establish especially in the South African public hospitals where the quality of healthcare services have been reported to have deteriorated.

Research purpose: The purpose of this study was to examine the relationship between psychological capital and organisational citizenship behaviour among nurses in the public hospitals.

Motivation for the study: There is crisis in the public nursing sector as nurses are reported to be working under pressure as a result of increased workload and responsibilities beyond their scope of practice (in terms of doing the work that they are not trained for and more work than they can handle), in addition to rapidly changing work environments.

Research approach, design and method: The present study follows a quantitative crosssectional design using a questionnaire on a sample of 228 nurses from public hospitals in the Eastern Cape Province, South Africa.

Main findings: The findings of the study confirm that psychological capital has a significant positive relationship with organisational citizenship behaviour.

Practical/managerial implications: The study recommends management to recognise the area of OCB in the public hospitals and work in nurturing and retaining those nurses capable of displaying such behaviours.

Contribution/value add: The study validates aspect of reciprocity of the Social exchange theory. Nurses with high levels of hope, self-efficacy, resilience and optimism showed reciprocity through the display of OCBs. The study also validates the aspect of job resources in eroding job demands from the Job demands resources model.

Keywords: psychological capital; organisational citizenship behaviour; public hospitals; operational efficiency; nurses; South Africa.

\section{Introduction}

Organisational citizenship behaviour (OCB) is vital in the working environment as it can be employed for human resource management in promoting both the quality of personnel and the services that organisations offer (Banwo \& Du, 2020). Specifically highlighting the definite state of OCB leads to the recognition of the status and the reliability of the organisation. In addition, behaviour-level items can also be utilised for personal evaluation as they are simple to measure (George \& Jones, 2008; Grego-Planer, 2019). The characteristics of OCB, for example, in terms of age, tenure and experience form a basis for in service by stage development to human resource management practitioners when targeted to individual employees and the organisation at large. In other studies (Joubert, Van Tonder, \& Grobler, 2018; Oparinde, Oparinde, \& Abdulsalam, 2019; Wang, Yang, Cao, \& Lee, 2019), OCB has also been reported to promote work quality, actual performance, service quality and service delivery and good reputation, and hence corporate image. The absence of OCB affects the organisational performance and its reputation.

The South African public hospitals have high rates of turnover and accidents (Weenink, Kool, Hesselink, Bartels, \& Westert, 2017). This has further resulted in poor-quality healthcare services 
and underperformance. Furthermore, nurses in public hospitals are reported to lack support, which affects performance. There is a massive skills shortage in the public health sector, and this affects the quality of healthcare services offered to the public (Mkonza, 2018). A total number of 15552 registered nurses are serving a population of 6498682 in the Eastern Cape province. This implies that one registered nurse is responsible for 417 patients (The South African Nursing Council, 2018). There is a crisis in the public nursing sector as a result of lack of preparation and support. This is a consequence of the rapidly changing work environment, which has caused an increased workload and responsibilities beyond the nurses' scope of practice (Maphumulo \& Bhengu, 2019).

Organisational citizenship behaviour has been defined by Organ (1988, p. 4) as 'individual behaviour that is discretionary, not directly or explicitly recognised by the formal reward system, and in the aggregate, promotes the efficient and effective functioning of the organisation'. Employees who engage in OCB are motivated to go the extra mile during task completion. Examples include assisting a fellow employee who is behind in their work or mentoring a new worker. Organisational citizenship behaviour is, therefore, an important aspect in hospitals as it results in improved patient care and the quality of health services (Organ, Podsakoff, \& MacKenzie, 2006).

Other scholars have also supported the above using the social exchange theory (Chernyak-Hai \& Rabenu, 2018; Konovsky \& Pugh, 1994; Spector \& Che, 2014). Social exchange theory derives a sense of reciprocity; thus, as organisational workers are presented with a conducive task environment, they would feel that they need to give something in return and they reciprocate through OCB (Chernyak-Hai \& Rabenu, 2018; Konovsky \& Pugh, 1994; Spector \& Che, 2014). Employees consider psychological capital (PsyCap) a vital element in the social exchange environment of the organisation and employees high in PsyCap also have a proactive personality (Li \& Crant, 2018; Machmud, 2018). Psychological strengths promote voluntary behaviour and research has identified PsyCap as a predictor of OCB in the working environment (Avey, Wernsing, \& Luthans, 2008). Psychological capital has its foundations from positive psychology and it is a motivational factor.

\section{Problem statement}

Organisational citizenship behaviour enhances effectiveness and workers' participation. It promotes teamwork and interorganisation cooperation in addition to minimising rates of errors and overall presents a good task environment (Balakrishnan \& Raman, 2020). Previous studies have identified the public health sector as one of the areas in which the issue of OCB seems critical (Issever, Soyuk, \& Sengun, 2016; Youssef, 2012; Yusof, Yaacob, \& Rahman, 2019). Hospital systems are endlessly undergoing innovative modifications that influence patient care and client management and most public hospital centres are failing to meet the demands, which are attached to the changes. It is considered that if nurses retained a higher level of OCB, there would have been a better chance for public hospitals to remain efficient (Yusof et al., 2019).

Organisational citizenship behaviour has been reported to support innovation and development through addressing and meeting the new demands of the organisation and the patients (Khaola, 2018). Demographic variations, innovation and increase in expectations of patients in the value of caring in the area of nursing added to a rising deficiency in the nursing workforce in general, and the turnover intentions of nurses in the public health sector have increased the importance of OCB amongst nurses in the same sector (Taghinezhad, Safavi, Raiesifar, \& Yahyavi, 2015).

Organisational types impact policies, practices and guidelines. In South Africa, hospitals managed by the private sector are flexible, for example, in monetary administration and staffing. In contrast, public hospitals are rigid. The deterioration in quality healthcare has led people to drop trust in the healthcare system in South Africa (Maphumulo \& Bhengu, 2019).

Some studies outline PsyCap as an antecedent of OCB (Bogler \& Somech, 2019). High OCB has been related with quality service care. However, OCB's contribution to quality services has a limited concept and empirical support (Almutawa, Muenjohn, \& Zhang, 2018; Sidin \& Arifah, 2019). The public healthcare system is a popular sector with significant attention from researchers and healthcare practitioners globally. This has prompted for a great amount research as a result of shortcomings and challenges in the sector (Maphumulo \& Bhengu, 2019). For this reason, this study was conducted to explain the role of PsyCap in enhancing OCB at public hospitals in Eastern Cape, South Africa.

\section{Research purpose and objectives}

The primary goal of this study is to investigate the impact of PsyCap on OCB in public hospitals in the Eastern Cape province of South Africa. This is important because the findings of this study will contribute to new knowledge about public hospitals as no previous studies could be identified with the same variables using a sample of nurses in public hospital in the Eastern Cape province. The public healthcare environment is characterised by poor working conditions and non-personalised conditions (Rutter, 2017). There is a shortage of nurses in the province and an unequal distribution of nurses in different areas. For example, a province like the Eastern Cape has a density of less than half that of the Western Cape and Gauteng (Dhai, 2018). Nurses comprise $80 \%$ of the overall health professionals in South Africa and in Eastern Cape their performance in terms of health outcomes when compared with other provinces is extremely poor (Passchier, 2017). 
In reference to the interdependence between nurses and patients, public hospitals need to promote OCB because it is critical. The evaluation of OCB amongst nurses is, therefore, important.

\section{Statement of hypothesis}

$\mathbf{H}_{\mathbf{1}}$ : There is a significant direct relationship between PsyCap and OCB.

$\mathbf{H}_{0}$ : There is no significant direct relationship between PsyCap and OCB.

\section{Literature review}

This section will define the variables of interest and explain the theories underpinning the study.

\section{Theoretical literature review}

This section will discuss the theories underlining the study.

\section{Social exchange theory}

The social exchange theory originated from the fields of economics, psychology and sociology (Homans, 1958). Social exchange behaviour has been conceptualised as the interchange of tangible or intangible elements like the signs of esteem or prestige. Individuals that offer more to others also expect more from them, and they are under pressure to deliver (Li \& Yu, 2017).

Blau (1986) further conceptualised social exchange as discretionary behaviours of employees that are derived by the proceeds they expect to receive from co-workers. Social exchange brings forth an expectancy of some forthcoming reward for contributions. It is based on an employee's trusting that the other part of the exchanges will objectively meet their obligations in the long run (Holmes, 1981). Social exchange theory explains how workers perceive their relationship with co-workers based on perceptions of: the balance between what one dedicated into the relationship and what they obtain from it, the kind of relationship that employees are worth and the probability of achieving a better relationship with a co-worker (Blau, 1986).

Employers exploiting social exchange theory utilise a lasting relationship with workers and are involved in their workers' welfare and career development and expect the loyalty and commitment to be mutual. When employees are treated with esteem, they are highly likely to exhibit OCBs (Cho \& Johanson, 2008). Other scholars also confirmed that managers' and supervisors' support promote employee OCB as a result of the social exchange relationship that is formed amongst employees, managers and supervisors (Organ, 1988; Podsakoff, MacKenzie, Paine, \& Bachrach, 2000). Related results have also occurred in the setting of co-workers' social exchange (Ilies, Nahrgang, \& Morgeson, 2007; Rhodes \& Eisenberger, 2002).

\section{The job demands resources model}

In the job demands resources (JD-R) model job characteristics are classified into two groups which are job-related demands and job-related resources (Leiter \& Bakker, 2010). Job-related demands are the physical, psychological, social or organisational traits of a task, which promote continued physical, cognitive and emotional effort or skills (Schaufeli \& Taris, 2014). These comprise pressure of work and emotional, mental or physical demands. Job resources refer to those physical, psychological, social or organisational aspects of the job that are either/or: practical in attaining work goals; lessen job demands and the related physiological and psychological costs; and stimulate personal growth, learning and development (Schaufeli \& Taris, 2014). Psychological capital is a psychological form of development associated with high levels of hope, selfefficacy, resilience and optimism and it also fulfils the other two stated aspects here.

According to the JD-R model, job resources such as PsyCap serve a significant part in fuelling an engagement process that results in OCB and in turn improves job performance (Kasaa \& Hassanb, 2015). Psychological capital adopts roles as intrinsic and extrinsic motivators. Intrinsic motivators include meaning, hope and self-efficacy. Job demands make task accomplishment difficult and erode the existence of OCB in the task environment. Job resources as extrinsic motivators achieve and retain employee well-being to enhance their drive to fulfil the accomplishment of their tasks (Okello \& Gilson, 2015). The conception of 'resource caravans' only takes place when individuals in possession of vast job resources experience more strengths for them to thrive in the work environment (Pheko, 2013). Such employees experience higher levels of consistency in both their objectives and personal development. As a result, these individuals are intrinsically and/or extrinsically stirred to put more emphasis on their objectives and in turn are highly engaged in their work roles and may be expected to evince high levels of OCB (Okello \& Gilson, 2015). In turn, OCB generates positive organisational outcomes.

\section{Conceptual literature review}

This section will highlight the main variables of the study.

\section{Psychological capital}

The term 'PsyCap' is defined as an employee's desirable psychological state of development, whose main features are high levels of hope, self-efficacy, resilience and optimism (Lorenz, Beer, Pütz, \& Heinitz, 2016). These paradigms are objectively different and denote an individual's positive frame of mind. Psychological capital is also a positive outlook of an employee about (not necessarily restricted to) his or her job and organisation (Levene, 2015). It is derived from the fundamentals of positive psychology that underline strengths and benefits rather than dysfunctions and flaws of employees (Peterson \& Park, 2003; Seligman, Csikszentmihalyi, \& Seligman, 2000). 
Hope refers to the desirable emotional state grounded in the possession of determination and pathways to fulfil objectives (Snyder, 2000). Self-efficacy refers to an employee's confidence of his or her capability to achieve work roles at an agreed level and results in the acceptance of challenges and partaking of the task (Bandura, 1997). Resilience is defined as the continuance of positive adjustment under challenging conditions (Masten \& Reed, 2002). Optimism refers to the state of always identifying the best in every situation whilst expecting the best outcomes (Jitendra, Jenny, Brian, \& Bharat, 2010).

Psychological capital has its roots from positive organisational scholarship, a field of psychology that aims to enhance personalities, competences and behaviour that lead to qualify employees to operate more efficiently (Robyn \& MitongaMonga, 2017).

Positive organisational behaviour provides a foundation of this study because it focuses on the creation of a positive work life and performance in the organisation. Psychological capital is a validated factor that positively enhances performance in the organisation (Bouzari \& Karatepe, 2017; Chen, 2017). It provides a series of resources that are important for the display of OCBs by employees and retaining expert and referent bases of power amongst nurses in public hospitals (Hou, Hsieh, \& Ngo, 2018). In the process, nurses are also empowered both directly and indirectly to improve the performance in their task environments. The high level of skill and power amongst nurses together with the worthiness and right to others' respect promotes performance and increases the quality of public healthcare services and the nurse's intention to stay in the public hospitals.

\section{Organisational citizenship behaviour}

Organisational citizenship behaviour refers to voluntary behaviour an employee displays that is not part of the formal task requirements and duties, which are not stated in the job description and they benefit others as well as the organisation (Organ, Podsakoff, \& MacKenzie, 2006). It comprises of five dimensions, which are altruism, conscientiousness, sportsmanship, courtesy and civic virtue (Organ, 1988; Podsakoff et al., 2000). Altruism refers to assisting coworkers generously without expecting anything in return. Workers involved in conscientiousness perform their duties in time and have high job engagement levels. Courtesy refers to the consideration of an individual's personal actions on co-workers. Workers demonstrating sportsmanship are more likely to be tolerant of inconveniences and impervious to gossiping on the job. Civic virtue relates to active participation in organisational governance and undertakings. Such employees are more concerned with organisational policies and being involved with issues important to organisational functioning (Organ, 1988; Podsakoff et al., 2000).

\section{Empirical literature review}

\section{The relationship between psychological capital and organisational citizenship behaviour}

Psychological capital is usually focused on goal accomplishment through an employee's ability to identify several ways (paths) (i.e. hope) to achievement, (i.e. hope, resilience and optimism) (Chen, Zeng, Chang, \& Cheung, 2019). In a study conducted in Iran, PsyCap was found to be significantly positively correlated with OCB (Pouramini \& Fayyazi, 2015). This is supported by other studies (Beal III, Stavros, \& Cole, 2013; Sepeng, 2016) using South African samples where PsyCap was found to be statistically significantly correlated with OCB; thus, employees with high PsyCap engaged more in OCB than those with low PsyCap.

Suifan (2016) used a sample of banking employees and the results of regression analysis showed that PsyCap had a significant positive correlation with OCB. Another study in the Indian context using a sample of manufacturing personnel confirmed PsyCap as a predictor of OCB (Pradhan, Jena, \& Bhattacharya, 2016). Thus, the positive psychological status of personnel stimulates voluntary behaviour such as assisting co-workers and completing a task jointly. A study by Somech and Khotaba (2017) using survey questionnaires in Israel also confirmed a significant positive relationship between PsyCap and OCB.

In another study on emotional intelligence, PsyCap and OCB, the results of correlational statistical analysis confirmed a positive and significant relationship between PsyCap and OCB (Azim \& Dora, 2016). Another quantitative study using a sample of academic employees found that the results supported a positive correlation between PsyCap and OCB (Rehman, Qingren, Latif, \& Iqbal, 2017). The investigation of PsyCap and OCB using a sample of nurses and administrative staff from a hospital in Iran reported a significant and positive relationship between PsyCap and OCB, implying that PsyCap supports positive performance in the organisation (Jahani, Mahmoudjanloo, Rostami, Nikbakht, \& Mahmoudi, 2018). Furthermore, in a study using the conservation resource theory a positive relationship between PsyCap and OCB was established (Hobfoll, Halbesleben, Neveu, \& Westman, 2018).

The positive relationship of PsyCap and OCB was also supported by Shukla and Singh (2013) and Sidra, Imran and Adnan (2016). More quantitative results validate the extant theories of PsyCap as a predictor of OCB. Qadeer and Jaffery (2014) studied PsyCap, organisational climate and OCB in the Middle East and found that PsyCap was positively associated with OCB. Equally, in another study, the results verified a positive association between PsyCap and OCB (Nikpay, Siadat, Hoveida, \& Nilforooshan, 2014). Nafei (2015) also investigated the impact of PsyCap on the quality of work life and OCB in a tertiary educational institution in India. The investigation reported a positive relationship between PsyCap and OCB. Murthy (2014) and Yu et al. (2018) also recorded a positive relationship of PsyCap with OCB. 
Nandan and Azim (2015) in their study on the influence of PsyCap and OCB in Malaysia using a sample of multimedia employees established that PsyCap is a predictor of OCB. In a study by Lather and Kaur (2015) on the relationship between PsyCap and OCB using an online questionnaire, the results showed that PsyCap promotes OCB. Similarly, Hakkak, Zarnegarian, Heydari and Ebrahimi (2015) conducted a quantitative study on PsyCap and OCB in an institution of higher learning in the Middle East and found that a positive and significant relationship exists between PsyCap and OCB. Another cross-sectional study indicated PsyCap to be a positive predictor of OCB (Cintantya \& Salendu, 2017).

PsyCap has a positive effect on individual employee behaviour and attitude (Williams, Kern, \& Waters, 2017). It determines the rate of task completion and motivates employees to perform more in the task environment (Luthans, Avolio, Avey, \& Norman, 2007). This is inconsistent with the study conducted by Jeong and Baek (2017) in Asia. The results of that study indicated that PsyCap was significantly and positively correlated with OCB. This is also supported by results from numerous studies, which proved a significant positive correlation between PsyCap and OCB (Malik \& Dhar, 2017; Min, Park, \& Kim, 2016; Tang \& Tsaur, 2016).

More research supports that PsyCap positively influences OCB (Karatepe \& Kaviti, 2016). This is in line with the study by Probst, Gailey, Jiang and Bohle (2017) where PsyCap was identified as a higher order construct with a positive significant relationship with OCB. In addition, a study conducted by Bouzari and Karatepe (2017) collected data from a sample of employees in the hospitality industry and established that PsyCap predicts OCB.

In another meta-analysis by Rachmawati and Priyono (2015), the results recorded PsyCap to be positively associated with OCB. A further study by Rego et al. (2017) using employees involved in teamwork showed that PsyCap predicts OCB. Similarly, a study by and Basmala and Prihatsanti (2017) also recorded PsyCap as a predictor of OCB. Prihatsanti (2017) using a sample of employees from Asia also confirmed that PsyCap has a positive effect on OCB.

An investigation by Mao and Tang (2015) using a sample of teachers also reported that PsyCap had a positive significant impact on OCB (Mao \& Tang, 2015). In a study using a sample of teachers, the results indicated that PsyCap had a positive significant impact on OCB. Furthermore, these findings were consistent with the results of the study by Ghorbani, Alizadeh, Khani and Mohamadi (2016). In their study using a sample of government employees, the results confirmed that OCB is positively influenced by high levels of hope, self-efficacy, resilience and optimism. In another study grounded in the social exchange theory (Khliefat, 2016), the results showed that PsyCap predicted higher levels of OCB. This further assists management in developing interventions to improve PsyCap in order to promote employee performance.
In a study using correlative methods through a Sobel test of significance, the results indicated a direct significant positive relationship between PsyCap and OCB (Sari, 2016). Psychological capital, therefore, contributes to individual employee's positive attitudes, which in turn influence positive behaviour at work. Additional studies also show that PsyCap is a predictor of OCB (Cohen, Mosley, \& Gillis, 2016; Gupta \& Kumar, 2015; Jung \& Yoon, 2015; Lee, Lyu, Chang, \& Shin, 2016). Hope, self-efficacy, resilience and optimism are, therefore, part of a supportive climate that promotes employee performance (Cohen, Mosley, \& Gillis, 2016).

Barbaranelli, Paciello, Biagioli, Fida and Tramontano (2019) in their study of positive work relationships established that PsyCap promotes job performance and OCBs. In addition, another study by Testa, Corsini, Gusmerotti and Iraldo (2018) showed that personal attitudes and PsyCap through selfefficacy influence OCB. This is also supported with other studies (Machmud, 2018; Shefer, Carmeli, \& Cohen-Meitar, 2018; Tüzün, Çetin, \& Basim, 2018) using samples of employees from different professions in Europe. Akin (2017) in his research using multiple regression analysis established that PsyCap through optimism predicts OCB.

Some scholars have challenged these findings. For instance, Putri (2016) and Hidayat (2015) in their studies concluded that no correlation was found between PsyCap and OCB amongst employees in the commercial sector. This may be because of the existence of incentives in the sector, which are already stated in the formal job description and serve as motivation to perform more on the job (Hidayat, 2015). In addition, a study by Goguen (2015) found that PsyCap predicted reduced OCB. In another study by Harris (2012) on PsyCap, work engagement and OCB, the results from multiple regression analysis showed no significant contributions to OCB by PsyCap. When comparing scores, small relationships between PsyCap scores and OCB scores, as well as their dimensions, were recorded.

\section{Literature gap}

Most of the studies employed samples of employees from the manufacturing and commercial industries (Arefin, Arif, \& Raquib, 2015; Newman, Schwarz, Cooper, \& Sendjaya, 2017; Suifan, 2016). This study will use a sample of public sector nurses to explore their levels of PsyCap and OCB. In addition, some previous studies investigated the variables excluding one or more of the other gender groups (Amadi, Jaja, \& Ukoha, 2017; Yu et al., 2017). This study will be conducted amongst both male and female registered hospital nurses. Other scholars also employed samples comprising mostly employees in big cities in 'high income' and 'middle income' countries and most samples were from metropolitan cities (Ginsburg et al., 2016; Newman et al., 2017; Yuriev et al., 2018). The present study was performed using a sample of nurses from an upper middle income country and a province where the healthcare system has been reported to be in crisis in relation to quality and access (Day, Gray, \& Ndlovu, 2018; 
TAC, 2018). Thus, in comparison with the previous studies, there are differences in the availability of opportunities and resources amongst the subjects of interest and hence this may also affect their PsyCap and OCB.

\section{Research design Research approach}

A cross-sectional survey was used because it permits the researcher to evaluate two or more variables at the same time and at a specific point in time. For example, this study considered PsyCap in relation to OCB simultaneously. Crosssectional surveys are also quick and inexpensive, and there is no manipulation of the study environment.

\section{Research method \\ Research participants}

The sample of this study consisted of nurses from five public hospitals in Amathole district in the Eastern Cape province of South Africa, namely, Victoria Hospital in Alice, Grey Hospital in King William's Town, Frere Hospital in East London, Winterburg Tuberculosis Hospital and Fort Beaufort Hospital, both in Fort Beaufort. A purposive sampling was used to select the hospitals. It was also used to address the issues around constraints of time, resources and access to information. The technique is adaptable and meets multiple needs and interests of research. It allows the researcher to draw generalisations from the sample of interest, which can be logical, analytic or theoretical in nature (Palys, 2008). Proportionate stratified random sampling was used to select a total of 228 nurses from different departments (both men and women) in the five selected hospitals. The population was separated into subgroups (such as area of specialisation) and then randomly selected from each of the subgroup. The size of each subgroup was proportionate to the population size of the strata when examined across the entire population. This was done to promote a uniform sampling fraction for each subgroup.

Of the 228 nurses, 13 (3.9\%) nurses who participated were below 21 years of age, $35(15.4 \%)$ were from 21 to 30 years old, $37(16.2 \%)$ were from 31 to 40 years old, 67 (29.4\%) were from 41 to 50 years old, $72(31.6 \%)$ were from 51 to 60 years old and only 4 people (3.5\%) were above 61 years of age. From the results, $22.8 \%$ of the people (52) who participated were men and $77.2 \%$ (176) were women. In total, 61\% (139) of participants were black people, $30.7 \%$ (70) were mixed race people, $7 \%$ (16) of participants were white people and only $1.3 \%$ (3) were Indians. In terms of tenure, 30.3\% (69) of the participants had worked for more than 16 years in their present job, 26\% (59) worked from 1 to 10 years in the present job, $24.1 \%$ (55) worked from 5 to 10 years in the current job, $12.7 \%$ (29) worked from 11 to 15 years in the current position and only $7 \%$ (16) were in their present job for less than a year.

Of the total participants, $49.6 \%$ (113) were married, 39.5\% (90) were single, $4.8 \%$ (11) were widowed, $4.4 \%$ (10) were divorced and only $1.8 \%$ (4) were separated. On the work status, $96.5 \%$
(220) were under full-time employment and only 3.5\% of participants (8) were employed part time. Departmentally, $19.7 \%$ (45) of the participants were working in theatre and casualty departments, $14.5 \%$ (33) paediatric, $10.5 \%$ (24) outpatient, $7.5 \%$ (17) intensive care, $7 \%$ (16) surgical, $6.6 \%$ (15) maternity, $5.3 \%$ (12) rehabilitation, $4.8 \%$ (11) medical and $4.4 \%$ (10) oncology. Lastly, regarding the highest qualification, $54.4 \%$ (124) of the participants had a Bachelor's degree, 14.9\% (34) had an Honours degree, 14\% (32) had a Master's degree, and $2.6 \%$ (6) had a Doctoral degree. The respondents on the 'Other' category had senior school certificates.

\section{Research instruments}

Self-administered questionnaires were used in this study as a means of data collection. The questionnaire comprised three sections: biographical data, the PsyCap Questionnaire (PCQ-24) and the Organisational Citizenship Behaviour scale.

\section{Psychological capital questionnaire}

The PCQ-24 (Luthans, Youssef, \& Avolio, 2007) was used to assess PsyCap. It is a 6-point 24-itemised rating scale, ranging from 1 = strongly disagree to $6=$ strongly agree. It comprises the following four subscales with the coefficient alpha indicated: self-efficacy (e.g. 'I feel confident that I can accomplish my work goals'), $\alpha=0.87$; hope (e.g. 'I have several ways to accomplish the work goal'), $\alpha=0.84$; optimism (e.g. 'At work, I always find that every problem has a solution'), $\alpha=0.80$; and resilience (e.g. 'I am undiscouraged and ready to deal with difficulties at work'), $\alpha=0.87$ (Luthans et al., 2007). In this study, the following Cronbach's alphas were obtained: hope $(\alpha=0.90)$, self-efficacy $(\alpha=0.80)$, optimism $(\alpha=0.86)$ and resilience $(\alpha=0.84)$.

\section{The Organisational Citizenship Behaviour scale}

The Organisational Citizenship Behaviour scale by Podsakoff, MacKenzie, Moorman and Fetter (1990) was used to measure OCB. It is a 7-point itemised rating scale, ranging from $1=$ strongly disagree to $7=$ strongly agree. The questionnaire has 24 items with five subscales: altruism (e.g. 'I willingly help new comers to get oriented towards the job'), $\alpha=0.88$; courtesy (e.g. 'I am mindful of how my behaviour affects other people's jobs'), $\alpha=0.87$; civic virtue (e.g. 'I keep myself updated with organisational announcements and memos'), $\alpha=0.84$; sportsmanship (e.g. 'I usually find fault with what my organisation is doing'), $\alpha=0.88$; conscientiousness (e.g. 'I don't take extra or long breaks whilst on duty'), $\alpha=0.85$. In this study, the following Cronbach's alphas were obtained: altruism ( $\alpha=0.86)$, courtesy ( $\alpha=0.84)$, civic virtue $(\alpha=0.90)$, sportsmanship ( $\alpha=0.82$ ) and conscientiousness $(\alpha=0.88)$.

\section{Research procedure and ethical considerations}

Approval to carry out the research was sought from the University of Fort Hare Research Ethics Committee (clearance number: MJO081SCHA01), The Department of Health (clearance number: EC_2017RP46_814), and the relevant authorities of the five hospitals of interest in the study. 
In conducting this research, the researcher observed and respected the rights and culture of the research participants. Anonymity and voluntary consent were always upheld. No personally identifying information was collected in the study.

During data collection, a short presentation was held before the distribution of the instrument in each department to introduce the research and clarify the data collection process to the respondents. This was done during normal working hours but without the disruption of the hospital work setting and it was stressed that participation of the respondents was voluntary and that they would not receive any reward or incentive for their participation.

A cover page with a statement assuring respondents that their data would only be used for academic purposes and would be kept confidential was attached to each questionnaire.

Respondents were given a maximum of 1 week to complete the questionnaire. The researcher collected the questionnaires in person during the normal hospital operating hours. Provision for nurses on night duty was also made. Of the anticipated 230 respondents who received questionnaires, 228 returned the completed questionnaires.

\section{Statistical analysis}

Data were analysed using Statistical Package for the Social Sciences (SPSS) version 24 (IBM, 2016). A Pearson correlational analysis together with linear regression analysis was used to determine whether PsyCap had a significant effect on OCB. Tests were carried out at $5 \%$ level of significance.

\section{Ethical consideration}

Ethical clearance to conduct the study was obtained from the Eastern Cape Department of Health Research Committee (clearance number: EC_2017RP46_814).

\section{Results}

\section{Reliability analysis}

The Cronbach's alpha coefficient for scales used in the study; the PCQ-24 and the organisational behaviour scale are $\alpha=0.85$ and $\alpha=0.89$, respectively. This shows that the measuring scales are reliable. For the subscales of each of the questionnaires, the Cronbach's alpha coefficients are shown under the section 'Research instruments'.

\section{Descriptive statistics}

Table 1 shows the summary of the descriptive statistics of the study. Data are displayed in terms of total number of respondents, mean scores, standard deviation, minimum, maximum, skewness and kurtosis of the data set from the sample.

It shows the mean levels of the variables that are score for the PsyCap (mean = 4.66; $\mathrm{SD}=1.17$ ); $\mathrm{OCB}($ mean $=4.74 ; \mathrm{SD}=1.10$ ) were all high for the study sample and this indicates the level of PsyCap and OCB the sample experienced and how their scores are distributed. The low standard deviation shows that the data are clustered closely around the mean, and therefore more reliable mean (Gurland \& Tripathi, 1971). Furthermore, the distribution of the responses from the questionnaires suggests that the data are very slightly negatively skewed, as it still falls in the -1.00 to +1.00 range. The Kurtosis for PsyCap and OCB are less than 3 , which shows that the light tailed relative to a normal distribution.

\section{Correlation analysis}

The association amongst the variables or components thereof was investigated using the Pearson product moment correlation coefficient and the results were as follows: $r=0.43 ; p<0.001$ for the relationship between PsyCap and OCB. We, therefore, accept the alternative hypothesis and conclude that there is a significant direct relationship between PsyCap and OCB.

The relationship between PsyCap and OCB was further tested using multiple regression analysis. The results in Table 3 show that a significant regression equation was found $(F=65.05 ; \beta=0.40 ; p<0.001 ; t=8.07)$. The adjusted $R^{2}$ of our model is 0.223 , which means that PsyCap accounts for only $22.3 \%$ of the total variance in OCB. It thus implies that many other factors that were not considered in the study

TABLE 1: Summary of descriptive statistics.

\begin{tabular}{|c|c|c|c|c|c|c|c|c|}
\hline Variable & $N$ & Mean & SD & Min & Max & Sum & Skewness & Kurtosis \\
\hline Psychological capital & 228 & 4.66 & 1.17 & 1 & 6 & 25461 & -1.17 & 1.68 \\
\hline Self-efficacy & 228 & 4.61 & 1.17 & 1 & 6 & 6302 & -1.21 & 1.98 \\
\hline Hope & 228 & 4.94 & 1.03 & 1 & 6 & 6757 & -1.41 & 2.60 \\
\hline Optimism & 228 & 4.35 & 1.37 & 1 & 6 & 5948 & -0.80 & 0.32 \\
\hline Resilience & 228 & 4.72 & 1.11 & 1 & 6 & 6454 & -1.24 & 1.83 \\
\hline Organisational citizenship behaviour & 228 & 4.74 & 1.10 & 1 & 6 & 25927 & -1.13 & 2.24 \\
\hline Altruism & 228 & 4.98 & 2.83 & 1 & 6 & 5677 & 0.10 & -1.33 \\
\hline Courtesy & 228 & 4.68 & 1.11 & 1 & 6 & 5339 & -1.10 & 2.90 \\
\hline Civic virtue & 228 & 4.35 & 1.23 & 1 & 6 & 3969 & -0.70 & 0.88 \\
\hline Sportsmanship & 228 & 4.45 & 1.27 & 1 & 6 & 5076 & -1.06 & 1.90 \\
\hline Conscientiousness & 228 & 5.15 & 0.94 & 1 & 6 & 5866 & -1.33 & 2.41 \\
\hline
\end{tabular}

SD, standard deviation. 
TABLE 2: Correlation of psychological capital and organisational citizenship behaviour.

\begin{tabular}{lcc}
\hline Variable & $\begin{array}{c}\text { Psychological } \\
\text { capital }\end{array}$ & $\begin{array}{c}\text { Organisational } \\
\text { citizenship behaviour }\end{array}$ \\
\hline Psychological capital & 1 & $0.43 \dagger$ \\
Pearson correlation & - & 0.00 \\
Sig. (1-tailed) & 228 & 228 \\
$N$ & & \\
Organisational citizenship behaviour & $0.43 \dagger$ & 1 \\
Pearson correlation & 0.00 & - \\
Sig. (1-tailed) & 228 & 228 \\
$N$ & & \\
\hline, , Correlation is significant at the 0.05 level (1-tailed). &
\end{tabular}

Sig, Significant.

TABLE 3: Model summary for the relationship between psychological capital and organisational citizenship behaviour.

\begin{tabular}{lcccccc}
\hline Variable & $\mathbf{R}$ & $\mathbf{R}^{2}$ & $\mathbf{B}$ & $\boldsymbol{t}$ & $\mathbf{F}$ & $\boldsymbol{p}$ \\
\hline Constant & \multirow{2}{*}{0.47} & 0.22 & 2.76 & 10.10 & \multirow{2}{*}{05.05} & 0.00 \\
PsyCap & & & 0.40 & 8.07 & & 0.00 \\
\hline
\end{tabular}

PsyCap, psychological capital; OCB, organisational citizenship behaviour.

Dependent variable: $\mathrm{OCB}$.

Predictors (constant): PsyCap.

could be responsible for the remaining $76.7 \%$ of variance in the relationship between PsyCap and OCB.

\section{Discussion of the results}

Psychological capital had a positive correlation with OCB. This may be because high levels of high self-efficacy, optimism, hope and resiliency may be a coping strategy to the challenges posed by the current work environment such as innovation; hence, employees who adapt to the challenges may be motivated to go the extra mile during task completion. For example, they might be involved in assisting a fellow employee who is behind in his or her job or mentoring new workers. This finding is consistent with that of Waters, Strauss, Somech, Haslam and Dussert (2020) who reported a positive and a statistically significant correlation between PsyCap and OCB.

More studies showed that PsyCap acts as an important resource that promotes OCB in organisations. In their study, Aderibigbe and Mjoli (2019) using a sample of graduate employees found a significant positive relationship between PsyCap and OCB. Another study by Lalita and Singh (2019) using a sample of school teachers also confirmed PsyCap as a form of management support, which promotes OCB, a form of the social exchange relationship that is formed amongst employees and management in the education sector.

The present results are in line with the findings of a study by Prihatsanti (2017) that emphasised that positive behaviour promotes extra role behaviour and consequently organisational success. Positively oriented human strengths and human capacities encourage the performance by employees that exceeds the minimum role requirements expected by the organisations (Kim, Kim, Newman, Ferris, \& Perrewé, 2019). These results are also further supported by another study by Rehman et al. (2017) who also found that there is a significant positive relationship between PsyCap and OCB.
The present results are also consistent with those of Machmud (2018) who established that PsyCap is a predictor of OCB. A significant and positive relationship between PsyCap and OCB is also supported by Bouzari and Karatepe (2017) who found that PsyCap motivates the exhibition of OCBs. Another study by Khosravizadeh et al. (2017) also supported the results of this study. The authors found that employees with high PsyCap have a positive approach to the task environment and that leads to the exhibition of extra role work behaviour. In addition, such employees are confident and optimistic about the work outcomes; hence, they exhibit voluntary work behaviours (Akin, 2017).

More scholars also showed that employees with high levels of PsyCap exhibit a positive behaviour and they are highly involved in organisational activities, and hence they also display higher levels of OCB (Testa et al., 2018). Psychological capital therefore is an important growth and development resource to such an extent that employees partake in other task complementing activities, which are not outlined in their job description voluntarily just to support the organisation (Grobler \& Joubert, 2018). More studies from Asia (Azim \& Dora, 2016; Jeong \& Baek, 2017) also support the results of this study. This may be because higher levels of PsyCap promote the establishment of a positive image about the organisation and this will lead to their display of OCB (Nandan \& Azim, 2015).

These results of the study provide support for the relevance of contingency theories such as the social exchange theory and the job demands resources (JD-R) model by highlighting the need of certain prevailing situational factors to influence organisational outcomes. The social exchange theory in perspective of organisational behaviour supports that a series of 'interdependent' interactions take place that are conditional on actions, which could determine the intrinsic or extrinsic behaviour of employees towards their organisation (Cropanzano \& Mitchell, 2005; Partina, Harsono, Sawitri, \& Haryono, 2019). Thus, an employee's resiliency, hope, selfefficacy and sense of optimism contribute significantly to bring out the 'good soldier' syndrome in an employee (Liaquat \& Mehmood, 2017).

The JD-R model provides a basis for understanding how workers respond to the job resources in the work environment. It is assumed that when intrinsic motivators such as selfefficacy, optimism, hope and resiliency (job resources) increase, job demands and the related psychological demands can be lessened, which will result in better performance in the organisation and thus promote employees to engage in OCB (Shim, Park, \& Jeong, 2019).

\section{Practical implications}

The outcome of the study presents a few directions for hospital managers. The positive association between PsyCap and OCB should encourage managers to strategise ways of involving the nurses by outlining fairly challenging 
task objectives for them. Challenging work objectives can, therefore, be outlined to nurses with high levels of PsyCap as this will lead to their engagement in OCB. It is imperative for management to recognise that nurses with high levels of PsyCap can be expected to be more active in the work environment and exert extra effort to assist co-workers in executing their tasks (Kim \& Park, 2017). Public hospitals depend solely on highly engaged human resources and, more specifically, on belief-driven, voluntary participation and consensus in most tasks, which may benefit overly from high levels of OCB.

Hospital managers and supervisors must encourage and nurture PsyCap in the psyche of nurses through trainings and seminars and conference exposure to promote OCB. In addition, it is also recommended to widen the scope of action of nurses within the nursing units, if possible. However, in order to strengthen $\mathrm{OCB}$, management must also be reminded that with the rising of $O C B$, tension (e.g. from time pressure and disruptions) reduces at the same time. The latter could contribute to increased pressure for nurses.

Hospital administrators need to be aware of the levels of nurses' occupational satisfaction and its triggers in order to develop and promote organisational citizenship behaviour. Hospital managers can nature workplace happiness amongst the nurses through maintaining social relationships with them, be concerned with their work-life balance and encourage open communication practices (Aderibigbe \& Mjoli, 2019).

Hospital management is also recommended to include workers in the organisational decision-making process and avoid prejudice and discrimination in meetings. Administrators must also develop a culture of periodically assessing the behaviour of nurses in the workplace through relevant interviews or surveys and also through monthly reports about their feelings of their jobs and their aspirations (Adatara et al., 2016). The outlined acts may restore the personal energy of nurses and reinforce their emotional relations with the hospitals in which they practise and in turn stimulate their OCBs.

\section{Limitations and recommendations}

The study was mainly focused on registered nurses in the public sector. Research conducted in the South African health sector shows that there are some differences between nurses' experiences in public and private hospitals (Pillay, 2009; Swart, Pretorius, \& Klopper, 2015). Future research could explore these variances and how they may relate to registered nurses' experiences of OCB in relation to PsyCap. In addition, OCB may, however, be influenced with external factors such as culture; therefore, it is recommended that future studies must explore the issue of culture on OCB across industries.

Another possibility for future research is the evaluation and comparison of various hospitals. Other investigators could also test the same study hypothesis in private hospitals to obtain more in-depth information on the two variables discussed in this article. Researchers in the field of human resources management may also collaborate with experts from other fields, such as public policy and sociology, to create more multidisciplinary research on the relationship between PsyCap and organisational citizenship behaviour in various public and private organisational contexts. Future research could also assess about why South African nurses often display OCBs and how nursing policymakers can improve such behaviours in the hospitals in South Africa.

\section{Conclusion}

In conclusion, the evidence from the findings and discussion showed that PsyCap influences OCB. This study makes theoretical contributions by providing information concerning the social exchange theory and the job resources demands model on their application to nursing practitioners. This research also offers useful insight into the importance of OCB amongst nurses in public hospitals. Knowledge obtained from this study allows hospitals to create better workplace conditions that place focus on OCB at work. Nurses are the face of the public health sector and they are considered as first responders. Their performance can therefore not be compromised, and the importance of OCB must not be underestimated in their working environment. Organisations must therefore continuously promote greater opportunities for displaying positive behaviours and outcomes that encourage OCB.

\section{Acknowledgements Competing interests}

The authors have declared that no competing interest exists.

\section{Authors' contributions}

S.F.C. is the main author of the article. The article is an extract from her PhD studies. T.Q.M. was the PhD supervisor who provided guidance and mentorship during the study. T.S.M. assisted with conceptual contributions.

\section{Funding information}

The University of Fort Hare Govan Mbeki Research and Development Centre assisted through a 2-year supervisory linked bursary to conduct this study.

\section{Data availability statement}

Data sharing is applicable to this study as new data were created and analysed in this study.

\section{Disclaimer}

The views and opinions expressed in this article are those of the authors and do not necessarily reflect the official policy or position of any affiliated agency of the authors. 


\section{References}

Adatara, P., Kuug, A., Nyande, F., Opare, F., Apaaye, M., Achaliwie, A., \& Dotse, W. (2016). A cross sectional study to examine perspective of nursing unit managers on factors affecting the effective performance of their roles in the Volta regional hospital, Ghana. Pyrex Journal of Nursing and Midwifery, 2(1), 1-6.

Aderibigbe, J.K., \& Mjoli, T.Q. (2019). Relationship between occupational stress, organisational citizenship behaviour, psychological capital and emotional intelligence among Nigerian employees. African Journal of Business and Economic Research, 14(1), 85-111. https://doi.org/10.31920/1750-4562/2019/V14n1a5

Akin, K. (2017). The effect of teachers' shared leadership perception on academic optimism and organizational citizenship behaviour: A Turkish case. International Journal of Leadership in Education, 20(2), 246-258. https://doi.org/10.1080/1360 3124.2015.1066868

Almutawa, Z.H., Muenjohn, N., \& Zhang, J. (2018). Attitudes and behaviors as predictors of service quality in the telecommunications sector context. International Journal of Quality \& Reliability Management, 35(3), 656-677. https://doi.org/10.1108/IJQRM-06-2016-0079

Amadi, B.Z., Jaja, S.A., \& Ukoha, D.O. (2017). An empirical study on relationship between employee engagement and organizational citizenship behavior in maritime firms, Onne, Nigeria. International Journal of Advanced Academic Research, Social \& Management Sciences, 3(2), 16-32.

Arefin, S., Arif, I., \& Raquib, M. (2015). The mediating role of psychological empowerment in the relationship between high-performance work systems and organizational citizenship behavior. European Scientific Journal, 11(2), 264-277.

Avey, J.B., Wernsing, T.S., \& Luthans, F. (2008). Can positive employees help positive organizational change? Impact of psychological capital and emotions on relevant attitudes and behaviors. The Journal of Applied Behavioral Science, 44(1), 48-70. https://doi.org/10.1177/0021886307311470

Azim, A.M., \& Dora, M. (2016). Perceived organizational support and organizational citizenship behavior: The mediating role of psychological capital. Journal of Human Capital Development, 9(2), 9.

Balakrishnan, L., \& Raman, M.R. (2020). The Influence of perceived hospital ethical climate on nurse's organisational citizenship behaviours. Our Heritage, 68(1) 1881-1887.

Bandura, A. (1997). Self-efficacy: The exercise of control. New York, NY: Freeman.

Banwo, A.O., \& Du, J. (2020). When the good outweighs the bad: Organizational citizenship behaviour (OCB) in the workplace. Human Resource Development International, 23(1), 88-97. https://doi.org/10.1080/13678868.2018.1449546

Barbaranelli, C., Paciello, M., Biagioli, V., Fida, R., \& Tramontano, C. (2019). Positivity and behaviour: The mediating role of self-efficacy in organisational and educational settings. Journal of Happiness Studies, 20(3), 707-727. https://doi. org/10.1007/s10902-018-9972-4

Basmala, B., \& Prihatsanti, U. (2017). The relationship between transformational leadership style and psychological capital of PDAM Tirta Moedal employees in Semarang [Hubungan antara gaya kepemimpinan transformasional dengan psychological capital pada pegawai PDAM Tirta Moedal Kota Semaran]. Jurnal Empati, 6(1), 45-53.

Beal, III, L., Stavros, J., \& Cole, M. (2013). Effect of psychological capital and resistance to change on organisational citizenship behaviour. SA Journal of Industrial Psychology/SA Tydskrif vir Bedryfsielkunde, 39(2), 11. https://doi.org/10.4102/ sajip.v39i2.1136

Blau, P. (1986). Exchange and power in social life. New Brunswick, NJ: Wiley \& Sons, Inc.

Bogler, R., \& Somech, A. (2019). Psychological capital, team resources and organizational citizenship behavior. The Journal of Psychology, 153(8), 784-802. https://doi.org/10.1080/00223980.2019.1614515

Bouzari, M., \& Karatepe, O. (2017). Test of a mediation model of psychological capital among hotel salespeople. International Journal of Contemporary Hospitality Management, 29(8), 2178-2197. https://doi.org/10.1108/IJCHM-01-2016-0022.

Chen, H.W. (2017). An empirical analysis of the influence of civil servants' psychological empowerment and job satisfaction on organizational citizenship behavior for the environment. Hong Kong: Lingnan University.

Chen, X., Zeng, G., Chang, E.C., \& Cheung, H.Y. (2019). What are the potential predictors of psychological capital for chinese primary school teachers? Frontiers in Education, 4, 50-58. https://doi.org/10.3389/feduc.2019.00050

Chernyak-Hai, L., \& Rabenu, E. (2018). The new era workplace relationships: Is social exchange theory still relevant? Industrial and Organizational Psychology, 11(3) 456-481. https://doi.org/10.1017/iop.2018.5

Cho, S., \& Johanson, M. (2008). Organizational citizenship behavior and employee performance: Moderating effect of work status in restaurant employees. Journal of Hospitality and Tourism Research, 32(3), 307. https://doi. org/10.1177/1096348008317390

Cintantya, H., \& Salendu, A. (2017). The relationship between psychological capital and organizational citizenship behavior among employees in Bank Syariah X. Depok: Universitas Indonesia.

Cohen, S., Mosley, D., \& Gillis, B. (2016). Transforming social capital: How psychological capital and emotional intelligence influence NCBIs. Academy of Management Proceedings, 2016(1), 12273-12280. https://doi.org/10.5465/ ambpp.2016.12273abstract

Cropanzano, R., \& Mitchell, M. (2005). Social exchange theory. An interdisciplinary review. JournalofManagement, 31(6),874-900. https://doi.org/10.1177/0149206305279602
Csikszentmihalyi, M., \& Seligman, M.E. (2000). Positive psychology: An introduction. American Psychologist, 55(1), 5-14. https://doi.org/10.1037/0003-066X.55.1.5

Day, C., Gray, A., \& Ndlovu, N. (2018). South African health review 2018. Durban: Health Systems Trust.

Dhai, A. (2018). Healthcare in crisis: A shameful disrespect of our constitution. South African Journal of Bioethics and Law, 11(1), 8-10. https://doi.org/10.7196/ SAJBL.2018.v11i1.00649

George, J.M., \& Jones, G. (2008). Understanding and managing organizational Behavior. Pearson, NJ: Pearson Education.

Ghorbani, V.Z., Alizadeh, H., Khani, S., \& Mohamadi, A. (2016). A structural model for the effect of psychological capital on organizational citizenship behavior. Research in Sports Management and Motor Behaviour Journal, 5(10), 95-106.

Ginsburg, L., Berta, W., Baumbusch, J., Rohit Dass, A., Laporte, A., Reid, R., ... Taylor, D. (2016). Measuring work engagement, psychological empowerment, and organizational citizenship behavior among health care aides. The Gerontologist, 56(2), e1-e11. https://doi.org/10.1093/geront/gnv129

Goguen, K.N. (2015). The mediating effects of positive psychological states on the relationships between hindrance stressors and organizational citizenship behaviors: A multi-level approach. Clemson, SC: Graduate School of Clemson University.

Grego-Planer, D. (2019). The relationship between organizational commitment and organizational citizenship behaviors in the public and private sectors. Sustainability, 11(22), 1-20. https://doi.org/10.3390/su11226395

Grobler, A., \& Joubert, Y.T. (2018). Psychological capital: Convergent and discriminant validity of a reconfigured measure. South African Journal of Economic and Management Sciences, 21(1), 1-14. https://doi.org/10.4102/sajems.v21i1.1715

Gupta, M., \& Kumar, Y. (2015). Justice and employee engagement. Asia-Pacific Journal of Business Administration, 7(1), 89-103. https://doi.org/10.1108/APJBA-04-2014-0048

Gurland, J., \& Tripathi, R.C. (1971). A simple approximation for unbiased estimation of the standard deviation. The American Statistician, 25(4), 30-32. https://doi.org/ 10.1080/00031305.1971.10477279

Hakkak, M., Zarnegarian, Y., Heydari, A.R., \& Ebrahimi, H.R. (2015). Research paper investigating the effects of psychological capital on organizational citizenship behavior - A case study of educational staff of Qom University. International Journal of Scientific Management and Development, 3(5), 372-376.

Harris, C. (2012). Relationships between psychological capital, work engagement and organisational citizenship behaviour in South African automative dealerships. Port Elizabeth: Nelson Mandela Metropolitan University.

Hidayat, M. (2015). The impact of job characteristic, work satisfaction, employee psychological capital on work performance with organizational citizenship behavior as a mediator (Study on BPRS Artha Surya Barokah Company). Journal Mahasiswa PascaSarjana, 2(1), 12-34.

Hobfoll, S.E., Halbesleben, J., Neveu, J.P., \& Westman, M. (2018). Conservation of resources in the organizational context: The reality of resources and their consequences. Annual Review of Organizational Psychology and Organizational Behavior, 5, 103-128. https://doi.org/10.1146/annurev-orgpsych-032117-104640

Holmes, J.G. (1981). The exchange process in close relationships: Microbehavior and macromotives. In J. Lerner \& C. Lerner (Eds.), The justice motive in social behavior (pp. 219-247). New York, NY: Plenum.

Homans, G. (1958). Social behavior as exchange. American Journal of Sociology, 63(6), 597-606. https://doi.org/10.1086/222355

Hou, W.K., Hsieh, H.L., \& Ngo, Q.N. (2018). Linking service-oriented organizational citizenship behavior, service climate, employees' work engagement via social support: A moderated mediation model based on conservation of resources theory. World Academy of Science, Engineering and Technology, International Journal of Psychological and Behavioral Sciences, 5(3), 12.

IBM. (2016, March 15). SPSS statistics 24. Chicago, IL: IBM.

Ilies, R., Nahrgang, J.D., \& Morgeson, F.P. (2007). Leader-member exchange and citizenship behaviors: A meta-analysis. Journal of Applied Psychology, 92(1), 269277. https://doi.org/10.1037/0021-9010.92.1.269

Issever, H., Soyuk, S., \& Sengun, H. (2016). P147 Organisational citizenship behaviour of the nurses working in public hospitals. Occupational and Environmental Medicine, 73(Suppl. 1), A169-A170. https://doi.org/10.1136/oemed-2016-103951.464

Jahani, M.A., Mahmoudjanloo, S., Rostami, F.H., Nikbakht, H.A., \& Mahmoudi, G. (2018). Datasets on organizational citizenship behavior in the selected hospitals with different ownership. Data in brief, 19, 288-292. https://doi.org/10.1016/j. with different ow 2018.05 .024

Jeong, H., \& Baek, Y. (2017). Meta-analysis of the impact of positive psychological capital on employees' outcomes: The moderating role of tenure. World Academy of Science, Engineering and Technology. International Journal of Social, Behavioral, Educational, Economic, Business and Industrial Engineering, 11(7), 1749-1753.

Jitendra, M., Jenny, S., Brian, L., \& Bharat, M. (2010). Optimism and longevity. Advances in Management, 3(3), 50-62.

Joubert, P., Van Tonder, E., \& Grobler, B. (2018). Perceived organisational support, job satisfaction and organisational citizenship behaviour of South African police service officials. The International Journal of Social Sciences and Humanity Studies, 10(1), 222-239. https://doi.org/10.20472/IAC.2018.039.020

Jung, H., \& Yoon, H. (2015). The impact of employees' positive psychological capital on job satisfaction and organizational citizenship behaviors in the hotel. Internationa Journal of Contemporary Hospitality Management, 27(6), 1135-1156. https://doi. org/10.1108/IJCHM-01-2014-0019 
Karatepe, O., \& Kaviti, R. (2016). Test of a mediational model of organization mission fulfillment: Evidence from the hotel industry. International Journal of Contemporary Hospitality, Management, 28(5), 988-1008. https://doi. Contemporary Hospitality, Manag

Kasaa, M., \& Hassanb, Z. (2015). The role of flow between burnout and organizational citizenship behavior (OCB) among hotel employees in Malaysia. Social and Behavioral Sciences, 211, 199-206. https://doi.org/10.1016/j.sbspro.2015.11.084

Khaola, P.P. (2018). Fostering innovative behaviours through leadership and fairness: Commitment and citizenship behaviours as successive mediators (Doctoral dissertation). Johannesburg: University of Witwatersrand.

Khliefat, A. (2016). The impact of the perceived challenge and hindrance stressors on the hotel frontline employees organizational citizenship behaviors: An empirical investigation to the moderating role of the psychological capital. Auburn, AL: Auburn University.

Khosravizadeh, O., Vatankhah, S., Alirezaei, S., Doosty, F., Mousavi Esfahani, H., \& Rahimi, M. (2017). Organizational Citizenship Behavior and its Relationship with Psychological Capital: A Survey of Hospital Staffs. Evidence Based Health Policy, Management and Economics, 1(1), 25-32.

Kim, M., Kim, A.C., Newman, J.I., Ferris, G.R., \& Perrewé, P.L. (2019). The antecedents and consequences of positive organizational behavior: The role of psychological capital for promoting employee well-being in sport organizations. Sport Management Review, 22(1), 108-125. https://doi.org/10.1016/j.smr.2018.04.003

Kim, W., \& Park, J. (2017). Examining structural relationships between work engagement, organizational procedural justice, knowledge sharing, and innovative work behavior for sustainable organizations. Sustainability, 9, 205. https://doi.org/ 10.1080/15332845.2016.1147936.

Konovsky, M.A., \& Pugh, S.D. (1994). Citizenship behavior and social exchange. Academy of Management Journal, 37(3), 656-669. https://doi. Academy of Mand
org/10.5465/256704

Lalita, S., \& Singh, S. (2019). Predicting organizational citizenship behavior among school teachers: The role of psychological capital. International Journal of Indian Psychology, 7(2), 62-71.

Lather, A.S., \& Kaur, M.S. (2015). Psychological capital as predictor of organizational commitment and organizational citizenship behavior. The International Journal of Indian Psychology, 2(4), 102-112. https://doi.org/10.25215/0204.069

Lee, K.H., Lyu, J., Chang, Y.C., \& Shin, Y.J. (2016). The effect of ethical management and positive psychological capital on organizational effectiveness in hospitals. Health Policy Manaement, 26(3),155-171. https://doi.org/10.4332/KJHPA.2016.26.2.155

Leiter, M.P., \& Bakker, A.B. (2010). Work engagement: Introduction. In M.P. Leiter \& A.B. Bakker (Eds.), Work engagement: A handbook of essential theory and research (pp. 1-9). London: Psychology Press.

Levene, R.A. (2015). Positive psychology at work: Psychological capital and thriving as pathways to employee engagement. Master of Applied Positive Psychology (MAPP) Capstone Projects, Paper (Vol. 88, pp. 1-54). Pennsylvania: University of Pennsylvania.

Li, H.Y., \& Yu, G.L. (2017). A multilevel examination of high-performance work systems and organizational citizenship behavior: A social exchange theory perspective. Eurasia Journal of Mathematics Science and Technology Education, 13(8), 58215835. https://doi.org/10.12973/eurasia.2017.01032a

Li, N.L., \& Crant, J.M. (2018). The role of proactive personality in job satisfaction and OCB-A relational perspective. Journal of Applied Psychology, 95(2), 395-404. https://doi.org/10.1037/a0018079

Liaquat, M., \& Mehmood, K. (2017). Organization citizenship behavior: Notion of social exchange theory. Journal of Business and Social Review in Emerging Economies, 3(2), 209-216. https://doi.org/10.26710/jbsee.v3i2.137

Lorenz, T., Beer, C., Pütz, J., \& Heinitz, K. (2016). Measuring psychological capital: Construction and validation of the compound PsyCap scale (CPC-12). PLoS One 11(4), e0152892. https://doi.org/10.1371/journal.pone.0152892

Luthans, F., Avolio, B.J., Avey, J.B., \& Norman, S.M. (2007). Positive psychological capital: Measurement and relationship with performance and satisfaction. Personnel Psychology, 60(3), 541-572. https://doi.org/10.1111/j.1744-6570.2007.00083.x

Luthans, F., Youssef, C.M., \& Avolio, B.J. (2007). Psychological capital: Developing the human competitive edge. Oxford: Oxford University Press.

Machmud, S. (2018). The influence of self-efficacy on satisfaction and workrelated performance. International Journal of Management Science and Business Administration, 4(4), 43-47. https://doi.org/10.18775/ ijmsba.1849-5664-5419.2014.44.1005

Malik, N., \& Dhar, R. (2017). Authentic leadership and it's impact on extra role behavior of nurses: The mediating role of psychological capital and the moderating role of autonomy. Personnel Review, 46(2), 277-296. https://doi.org/10.1108/PR 05-2015-0140

Mao, J.P., \& Tang, C. (2015). Team psychological capital and teachers organizational citizenship behavior: The mediating role of job satisfaction. Chinese Journal of Clinical Psychology, 23(4), 736-740.

Maphumulo, W.T., \& Bhengu, B.R. (2019). Challenges of quality improvement in the healthcare of South Africa post-apartheid: A critical review. Curationis, 42(1), 1-9. https://doi.org/10.4102/curationis.v42i1.1901

Masten, A.S., \& Reed, M.J. (2002). Resilience in development. In C. Snyder \& S. Lopez (Eds.), Handbook of positive psychology (pp. 74-88). Oxford: Oxford University.

Min, H., Park, J., \& Kim, H.J. (2016). Common method bias in hospitality research: A critical review of literature and an empirical study. International Journal of critical review of literature and an empirical study. International Journal of
Hospitality Management, 56, 126-135. https://doi.org/10.1016/j. Hospitality Manad
Mkonza, T. (2018, June 26). Critical shortage of skilled nurses, warns MEC. Pretoria: IOL.

Murthy, R.K. (2014). Psychological capital, work engagement and organizational citizenship behaviour. Sinhgad Institute of Management and Computer Application (SIMCA), 1(1), 347-358.

Nafei, W. (2015). Meta-analysis of the impact of psychological capital on quality of work life and organizational citizenship behavior: A study on Sadat City University. International Journal of Business Administration, 6(2), 42-64. https://doi. org/10.5430/ijba.v6n2p42

Nandan, T., \& Azim, A. (2015). Organizational justice and organizational citizenship behavior: Mediating role of psychological capital. American International Journal of Social Science, 4(6), 148-153.

Newman, A., Schwarz, G., Cooper, B., \& Sendjaya, S. (2017). How servant leadership influences organizational citizenship behavior: The roles of LMX, empowerment, and proactive personality. Journal of Business Ethics, 145(1), 49-62. https://doi. org/10.1007/s10551-015-2827-6

Nikpay, I., Siadat, S., Hoveida, R., \& Nilforooshan, P. (2014). A model for investigating the impact of faculty members' psychological capital on organizational citizenship behaviors in universities. International Journal of Management Sciences, 2(6), 161-168.

Okello, B., \& Gilson, L. (2015). Exploring the influence of trust relationships on motivation in the health sector: A systematic review. Human Resources for Health, 13, 3-18. https://doi.org/10.1186/s12960-015-0007-5

Oparinde, F., Oparinde, O., \& Abdulsalam, A. (2019). The influence of job satisfaction on organisational citizenship behaviour in Osun State-owned tertiary institutions. African Journal of Inter/Multidisciplinary Studies, 1(1), 49-60.

Organ, D.W. (1988). Organizational citizenship behaviour: The good soldier syndrome. Lexinton, MA: Lexinton Books.

Organ, D.W., Podsakoff, P.M., \& MacKenzie, S.B. (2006). Organizational citizenship behavior: Its nature, antecedents, and consequences. Thousand Oaks, CA: Sage.

Palys, T. (2008). Purposive sampling. In L. Given (Eds.), The Sage encyclopedia of qualitative research methods (pp. 697-698). Los Angeles, CA: Sage.

Partina, A., Harsono, M., Sawitri, H., \& Haryono, T. (2019). The predictor of organizational citizenship behaviour using social exchange theory. International Journal of Scientific and Research Publications, 9(5), 514-518. https://doi. Journal of Scientific and Research
org/10.29322/IJSRP.9.05.2019.p8961

Passchier, R.V. (2017). Exploring the barriers to implementing National Health Insurance in South Africa: The people's perspective. South African Medical Journal, 107(10), 836-838. https://doi.org/10.7196/SAMJ.2017.v107i10.12726

Peterson, C., \& Park, N. (2003). Positive psychology as the evenhanded positive psychologist views it. Psychological Inquiry, 14(2), 143-147.

Pheko, M.M. (2013). The impact of resource loss and resource gain among Botswana employees: A test of the conservation of resources theory. International Journal of Business and Social Science, 4(4), 151-162.

Pillay, R. (2009). Retention strategies for professional nurses in South Africa. Leadership in Health Services, 22(1), 39-57.

Podsakoff, P.M., MacKenzie, S.B., Moorman, R.H., \& Fetter, R. (1990). Transformational leader behaviors and their effects on followers' trust in leader, satisfaction, and organizational citizenship behaviors. The Leadership Quarterly, 1(2), 107-142. https://doi.org/10.1016/1048-9843(90)90009-7

Podsakoff, P.M., Mackenzie, S.B., Paine, J.B., \& Bachrach, D.G. (2000). Organizational citizenship behaviour: A critical review of the theoretical and empirical literature and suggestions for future reserch. Journal of Management, 26(3), 513-556. https://doi.org/10.1177/014920630002600307

Pouramini, Z., \& Fayyazi, M. (2015). The relationship between positive organizational behavior with job satisfaction, organizational citizenship behavior, and employee engagement. International Business Research, 8(9), 57-66. https://doi. org/10.5539/ibr.v8n9p57

Pradhan, R.K., Jena, L.K., \& Bhattacharya, P. (2016). Impact of psychological capital on organizational citizenship behavior: Moderating role of emotional intelligence. Cogent Business \& Management, 3(1), 16. https://doi.org/10.1080/23311975. 2016.1194174.

Prihatsanti, U. (2017). The role of psychological capital among Indonesian's worker Journal of Educational, Health and Community Psychology, 6(3), 68-83. https:// doi.org/10.12928/jehcp.v6i3.8319

Probst, T.M., Gailey, N.J., Jiang, L., \& Bohle, S.L. (2017). Psychological capital: Buffering the longitudinal curvilinear effects of job insecurity on performance. Safety Science, 100, 74-82. https://doi.org/10.1016/j.ssci.2017.02.002

Putri, M.D. (2016). The impact of positive psy capital, job satisfaction on organizational citizenship behavior of Blue Sky Pandurata Hotel in Jakarta [Pengaruh positive psy capital, job satisfaction terhadap organizational citizenship behavior Blue Sky Panduratadi Jakarta]. Jakarta: Universitas Trisakti.

Qadeer, F., \& Jaffery, H. (2014). Mediation of psychological capital between organizational climate and organizational citizenship behavior. Pakistan Journal of Commerce and Social Sciences, 8(2), 453-470.

Rachmawati, E., \& Priyono, B. (2015). The influence of job characteristics and psychological capital on organizational citizenship behavior with moderation of person organization fit (A study on the department of revenue, management, person organization fit (A study on the department of revenue, management,
finance, and asset in Patiregency). Journal Mahasiswa Pasca Sarjana, 2(1), 76-92.

Rego, A., Owens, B., Yam, K., Bluhm, D., Cunha, M., Silard, A., ... Liu, W. (2017). Leader humility and team performance: Exploring the mediating mechanisms of team PsyCap and task allocation effectiveness. Journal of Management, 45(3), 1009-1033. https://doi.org/10.1177/0149206316688941 
Rehman, S.U., Qingren, C., Latif, Y., \& Iqbal, P. (2017). Impact of psychological capital on occupational burnout and performance of faculty members. International
Journal of Educational Management, 31(4), 455-469. https://doi.org/10.1108/ Journal of Educational
IJEM-01-2016-0011

Rhodes, L., \& Eisenberger, R. (2002). Perceived organizational support: A review of the literature. Journal of Applied Psychology 87(4), 698-714. https://doi. org/10.1037/0021-9010.87.4.698

Robyn, C.M., \& Mitonga-Monga, J. (2017). Psychological capital and work engagement in relation to employee commitment in a South African manufacturing organisation. Journal of Contemporary Management, 14(1), 702-730.

Rutter, L. (2017). Detailed report on the state of Limpopo Health system. Limpopo: Treatment Action Campaing.

Sari, D. (2016). The role of quality of work life (QWL) as a mediator in the relationship of psychological capital (PsyCap) with organizational citizenship behavior (OCB) in civil servants (PNS) in Buleleng regency. Proceedings of the National Conference of Young Indonesian Psychology Researchers, vol. 1, no. 1, pp. 85-93. Jakarta: ICYSS.

Schaufeli, W., \& Taris, T. (2014). A critical review of the job demands-resources model: Implications for improving work and health. In G.F. Bauer \& O. Hämmig (Eds.) Bridging occupational, organizational and public health: A transdisciplinary approach (pp. 43-68). Dordrecht: Springer. https://doi.org/10.1007/978-94-007-5640-3 4

Sepeng, W. (2016, May 24). Authentic leadership, organisational citizenship behaviou and intention to leave: The role of psychological capital. Vanderbijlpark: North West University.

Shefer, N., Carmeli, A., \& Cohen-Meitar, R. (2018). Bringing carl rogers back in Exploring the power of positive regard at work. British Journal of Management, 29(1), 63-81. https://doi.org/10.1111/1467-8551.12247

Shim, D.C., Park, H.H., \& Jeong, S.Y. (2019). Government employees' organizational citizenship behavior amid organizational resource decline: Can they work more with less? Review of Public Personnel Administration, 39(2), 209-231. https://doi. org/10.1177/0734371X17715501

Shukla, A., \& Singh, S. (2013). Psychological capital \& citizenship behavior: Evidence from telecom sector in India. Indian Journal of Industrial Relations, 49(1), 97-110.

Sidin, I., \& Arifah, N. (2019). Organizational climate enhance service quality through enhancing OCB in public hospital. Biomedical Research, 30(5), 738-746. https:// doi.org/10.35841/biomedicalresearch.30-19-304

Sidra, S., Imran, B., \& Adnan, A. (2016). Moderating role of psychological capital between perceived organizational support and organizational citizenship behavio and its dimensions. International Journal of Research Studies in Psychology, 5(2), 41-50. https://doi.org/10.5861/ijrsp.2016.1375

Snyder, C.R. (2000). Handbook of hope. San Diego, CA: Academic Press.

Somech, A., \& Khotaba, S. (2017). An integrative model for understanding team organizational citizenship behavior. Journal of Educational Administration, 55(6), 671-685. https://doi.org/10.1108/JEA-09-2016-0104

Spector, P.E., \& Che, X.X. (2014). Re-examining citizenship: How the control of measurement artifacts affects observed relationships of organizational citizenship behavior and organizational variables. Human Performance, 27(2), 165-182. https://doi.org/10.1080/08959285.2014.882928
Suifan, T. (2016). The impact of organizational climate and psychological capital on organizational citizenship behaviour. International Journal of Business and Management, 11(1), 224-230. https://doi.org/10.5539/ijbm.v11n1p224

Swart, R. P., Pretorius, R., \& Klopper, H. (2015). Educational background of nurses and their perceptions of the quality and safety of patient care. Curationis, 38(1), 1-8.

TAC. (2018). State of provincial healthcare system. Cape Town: Treatment Action Campaign.

Taghinezhad, F., Safavi, M., Raiesifar, A., \& Yahyavi, S.H. (2015). Antecedents of organizational citizenship behavior among Iranian nurses: A multicenter study. BMC Research Notes, 8(1), 557-565. https://doi.org/10.1186/s13104-015-1505-1

Tang, Y., \& Tsaur, S. (2016). Supervisory support climate and service-oriented organizational citizenship behavior in hospitality: The role of positive group affective tone. International Journal of Contemporary Hospitality Management 28(10), 2331-2349. https://doi.org/10.1108/IJCHM-09-2014-0432

Testa, F., Corsini, F., Gusmerotti, N.M., \& Iraldo, F. (2018). Predictors of organizational citizenship behavior in relation to environmental and health \& safety issues. The International Journal of Human Resource Management, 1(1), 1-34.

The South African Nursing Council. (2018). 2018 Annual report. Pretoria: South African Nursing Council.

Tüzün, I.K., Çetin, F., \& Basim, H.N. (2018). Improving job performance through identification and psychological capital. International Journal of Productivity and Performance Management, 67(1), 155-170. https://doi.org/10.1108/ IJPPM-03-2016-0060

Wang, X.H., Yang, J., Cao, R., \& Lee, B.Y. (2019). Corporate social responsibility and collective OCB: A social identification perspective. Frontiers in Psychology, 10, 1-11. https://doi.org/10.3389/fpsyg.2019.02720

Waters, L., Strauss, G., Somech, A., Haslam, N., \& Dussert, D. (2020). Does team psychological capital predict team outcomes at work? International Journal of Wellbeing, 10(1), 1-25.

Weenink, J.W., Kool, R.B., Hesselink, G., Bartels, R.H., \& Westert, G.P. (2017). Prevention of and dealing with poor performance: an interview study about how professional associations aim to support healthcare professionals. Internationa Journal for Quality in Health Care, 29(6), 838-844. https://doi.org/10.1093/ intqhc/mzx114

Williams, P., Kern, M.L., \& Waters, L. (2017). The role and reprocessing of attitudes in fostering employee work happiness: An intervention study. Frontiers in Psychology, 8(28), 13-40. https://doi.org/10.3389/fpsyg.2017.00028

Youssef, C.M. (2012). Positive global leadership. Journal of World Business, 47(4), 539-547. https://doi.org/10.1016/j.jwb.2012.01.007

Yu, H. Y., Lou, J. H., Eng, C. J., Yang, C. I., \& Lee, L. H. (2018). Organizational citizenship behaviour of men in nursing professions: Career stage perspectives. Collegian, 25(1), 19-26

Yuriev, A., Boiral, O., \& Guillaumie, L. (2020). Evaluating determinants of employees pro-environmental behavioral intentions. International Journal of Manpower, 1(1), 1-15

Yusof, J., Yaacob, H.F., \& Rahman, S.A. (2019). The effects of psychological empowerment on organisational citizenship behaviour among Malaysian nurses. Management Research Spectrum, 9(1), 48-53. 